\title{
Science in the Arab world
}

\section{The immense challenges facing those who attempt to support research in developing countries are compounded by political turmoil in the Middle East.}

E our years ago, Nature reported on some welcome news from the Arab world. After years of declining investment in research, Arab states had begun to spend more on science and technology. The increases were modest and began from a low base, but they were happening in many countries that, owing to low oil prices, were experiencing falling national incomes at the time.

At the same moment, a new pan-Arab funding and networking organization had emerged. The Arab Science and Technology Foundation (ASTF), based in Sharjah in the United Arab Emirates - one of the region's most dynamic territories - aimed to function much like a national science-funding agency, offering grants to scientists based on an open, competitive process and peer review (see Nature 416, 120-122; 2002).

Nothing Earth-shattering here, you might think - except that in many developing countries, such agencies are under-funded, overly bureaucratic, and lacking in transparency and the in-house capacity to judge quality. It was partly to avoid these pitfalls that the ASTF set itself up as a non-profit foundation at arm's length from governments, instead seeking finance from the private sector. The foundation also aimed to encourage expatriate Arab scientists in Europe and the United States to work with scientists from home, and to link investors with researchers, holding workshops on topics such as entrepreneurship and intellectual property.

The importance of such activity cannot be overstated. The countries of the Middle East and North Africa are near the bottom of the global league tables for patents and trademarks. Foreign investment into, and high-technology exports from, Arab nations are also among the lowest in the world. As more Arab nations join the World Trade Organization - Saudi Arabia is the latest to do so the ASTF wants the region's scientists to help their nations compete in global markets.

\section{Changing relationships}

The foundation's grants programme is now established in fields such as water desalination, cellular telephony, materials science, robotics and biomedical research. And the organization has grown more ambitious. For example, there was no meeting where the Arab world's scientists could get together and learn about each others' work. So the ASTF started one: the biennial Scientific Research Outlook Symposium. The 2004 event in Riyadh, Saudi Arabia, attracted 850 scientists, twice the number of the previous meeting.

Unusually for a scientific body, the ASTF has engaged in difficult public-policy issues, including one of the region's biggest problems: the future of Iraq. Despite widespread scepticism in the Arab world about the invasion, and the murder of many scientists in Iraq (see page 1036), the foundation is working with the country's government to help reorganize science there.

This month, the ASTF announced its most ambitious programme

to date: Izdihar, which is Arabic for prosperity. The programme's aim is to raise quality of life in Arab societies, partly through the commercialization of knowledge. Under Izdihar, the ASTF promises to develop research-based solutions for problems in agriculture, energy, the environment and health care - and even governance.

Izdihar's designers argue that the region's problems are so severe that the ASTF's current activities, no matter how successful, are unequal to them. What is needed, they believe, is a strategic vision with science, technology and commerce at its core. The project is a big idea, and the result of Arab scientists' belief that they are privileged and therefore must shape a better future for those less fortunate. What its designers must now do is to explain how they intend

"In seeking to harness research and enterprise to alleviate poverty and underdevelopment, the Izdihar project demonstrates both vision and a sense of civic responsibility." would span the Muslim world (see Nature 432, 273-274; 2004). The fund would see science spending set aside and administered by a group of international trustees, making it hard for governments to spend the money on other things.

The scheme was championed by Pakistan's President Pervez Musharraf, and endorsed by the science ministers of the 57 member states of the Organization of the Islamic Conference. But it has failed to excite the governments that would have paid for a lot of it, such as those of Kuwait and Saudi Arabia. Without their support, the fund will probably be stillborn.

In contrast to this pattern of unfulfilled promise, the ASTF has worked hard to show that it means what it says. It offers hope in a realm of pervasive pessimism. And in seeking to harness research and enterprise to alleviate poverty and underdevelopment, the Izdihar project demonstrates both vision and a sense of civic responsibility.

But Izdihar is unlike anything that the foundation has embarked upon before. The organization's supporters - including the Arab investors and donors who would pay for the project and the scientists who would do the work - will have to be convinced that the foundation can deliver. The ASTF must therefore show not just a clear grasp of the problems, but also that it understands their solutions, and that it can mobilize the necessary resources. That will be a challenge, even for an organization that has shown so much early promise. 